\title{
The Legal Politics of Recall Right of Political Parties Relevance with the System of Popular Sovereignty In Dynamics of the Constitution of Indonesia
}

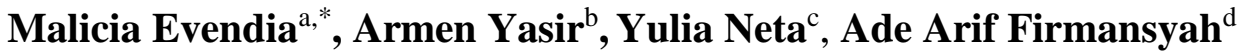 \\ ${ }^{a, b, c, d}$ Faculty of Law Lampung University, Lampung, Indonesia \\ *e-mail : maliciaevendia@yahoo.com
}

\begin{abstract}
The existence of regulation of recall rights of political parties as regulated in Law No. 17 of 2014 and Law No. 2 of 2008 bring a great influence on the position of legislative members. Based on these rules, legislators may be dismissed from their positions if proposed by Political Party. This certainly brings a polemic for the people as the sovereign owner, who have chosen their representatives through the electoral process, but when chosen representatives of the people can be dismissed from his position by a political parties through the mechanism of the right of recall. This research was done by doctrinal method approach as well as the use of the statute, historical, and conceptual approach. This results showed that the legal politics of recall right of political parties is actually only used as an instrument of the political parties in controlling its members in parliament in order to always adhere to the party's policy direction. This makes the recall right political party is legal products that characterized conservative or orthodox. The existence of a political party's recall rights order gives a great authority to the political parties to negate the result of the people's choice as the holder of sovereignty for the sake of the political party. The function of political parties as a means of political recruitment in the process of filling political office in this case as members of the legislature, should have been completed after the people chose their representatives through electoral mechanisms. Therefore, it is necessary for the reconstruction of the ideal and relevant recall rights arrangement to the people's sovereignty.
\end{abstract}

Keywords: Legal Politics, Recall, Sovereignty of the People, Political Party.

\section{INTRODUCTION}

Indonesia is a democratic country. In this understanding, the people have a very important position, because sovereignty is in the hands of the people. Article 1 Paragraph 
(2) of the 1945 Constitution of the State of the Republic of Indonesia (the 1945 Constitution) states that "Sovereignty is in the hands of the people and carried out according to the Constitution". The provision of Article 1 paragraph (2) is a legal political corridor ${ }^{1}$ in manifesting the meaning of people's sovereignty in the regulation of representative institutions of the people.

Kusnardi and Harmaily Ibrahim argued that it is the people who are regarded as owners and holders of supreme authority in a country. ${ }^{2}$ As the owner and the holder of power, the people determine the style and manner of governance organized, and determine the goals to be achieved state. ${ }^{3}$ In the 1945 Constitution, people's sovereignty is exercised through a representation system. Jimly Asshidiqie states that the sovereignty of the people with a system of representative or common democracy is also called a representative democracy system (representative democracy) or indirect democracy (indirect democracy). ${ }^{4}$

In the practice of state administration, the filling of representative institutions is carried out through General Election (Election). Election is one of the instruments to realize the sovereignty of the people who intend to form a legitimate government and a means of articulating the aspirations and interests of the people..$^{5}$ Therefore, in the development of the modern state, elections are a milestone for democracy.

\footnotetext{
${ }^{1}$ Etymologically, the legal term of law comes from the Dutch term, rechtspolitiek. From this term there are two syllables namely rechts which means law, and the law itself comes from the Arabic word hukm plural of ahkam, which means decree, decrees, command, government, power, punishment and so on. In the Dutch language dictionary the word politiek contains beleid meaning. The word beleid itself in Indonesian means policy. From this etymological understanding it can be said that legal politics is a legal policy. The policy itself in the Great Indonesian dictionary is a set of concepts and principles that outline and plan the basis for implementing a leadership hire, and how to act. When it is associated with this understanding then legal politics is a series of concepts and principles that outline and basic plan in the implementation of a job, leadership and how to act in the field of law.Yasir, Armen. (2010). Makalah Bahan Kuliah Politik Hukum. Lampung: Universitas Lampung, p. 1.

${ }^{2}$ Kusnardi, Moh. and Ibrahim, Harmaily. (1983). Pengantar Hukum Tata Negara Indonesia. Jakarta: PSHTN FHUI, p. 328.

${ }^{3}$ Asshidiqie, Jimly. (2006). Pengantar Ilmu Hukum Tata Negara Indonesia. Jakarta: Sekretariat Jenderal dan Kepaniteraan Mahkamah konstitusi, p. 168.

${ }^{4} I$ bid, p. 328. According to Jimly, the relationship between the people and the daily power of the State usually develops on the basis of two theories, namely the theory of direct democracy (direct democracy) in which the sovereignty of the people can be done directly in the sense of the people themselves who exercise the highest authority it has, and indirect theory of democracy (representative democracy). In modern times today with the complexity of the problems encountered, the teachings of indirect democracy, or often called representative democracy, are becoming more popular today. Usually the implementation of this sovereignty is called a representative institution. Asshiddiqie, Jimly. (1994). Gagasan Kedaulatan Rakyat Dalam Konstitusi dan Pelaksanaannya Di Indonesia. Jakarta: PT Ichtiar Baru Van Hoeve, p. 70.

${ }^{5}$ Tricahyo, Ibnu. (2009). Reformasi Pemilu Menuju Pemisahan Pemilu Nasional dan Lokal. Malang: In-Trans Publishing, p. 6.
} 
The realization of the people's sovereignty through direct election as a means for the people to elect their representatives has been affirmed in Article 22E of the 1945 Constitution namely "Elections are held to elect members of the People's Legislative Assembly, Regional Representative Council, President and Vice President and House of Representatives Area". The more complete regulation is regulated in Law Number 7 Year 2017 on General Election.

The recruitment process for membership of the people's representative is based on political parties, so that no single member of the council is not bound by a political party. As stated in Article 22E Paragraph (3) of the 1945 Constitution that "the participants of the general election to elect members of the People's Legislative Assembly and members of the Regional People's Legislative Assembly shall be political parties."

Members of House of Representatives (DPR) and Regional People's Representative Assembly (DPRD) besides can be selected, may also be dismissed from office. The provisions concerning the reasons for the termination of time between members of the representative body are stipulated in Article 239 paragraphs (1) and (2), Article 355 paragraphs (1) and (2), and Article 405 paragraph (1) and (2) of Law Number 172014 on the People's Consultative Assembly, the House of Representatives, the Regional Representative Council and the Regional People's Legislative Assembly (MD3 Law). Article 239 paragraph (1) states that members of the DPR shall terminate from time to time because:

1. died;

2. resign; or

3. dismissed.

Article 239 paragraph (2) of the MD3 Law further explains that members of the DPR shall be dismissed from time to time if:

1. unable to carry out their duties continuously or remain as members of the People's Legislative Assembly for 3 (three) consecutive months without any explanation;

2. violating the oath / pledge of office and the code of ethics of the People's Legislative Assembly;

3. be found guilty on the basis of a court decision that has obtained permanent legal force for committing a crime under penalty of 5 (five) years or more;

4. not attend plenary and / or meeting meetings of DPR parliament which become its duties and obligations as much as 6 (six) times in a row without valid reason;

5. proposed by its political party in accordance with the provisions of legislation;

6. no longer qualify as a candidate for member of the People's Legislative Assembly in accordance with the provisions of legislation regarding elections;

7. to violate the prohibition provisions as regulated in this Law; 
8. to be dismissed as a member of a political party in accordance with the provisions of laws and regulations; or

9. become a member of another political party.

Provisions concerning interim termination of members of the DPR as referred to in Article 239 paragraphs (1) and (2) shall apply mutatis mutandis to the interim termination of members of the DPRD.

There is an interesting point in the provision of interim termination of members of the DPR and DPRD, namely the reason for the dismissal of members of DPR and / or DPRD from their positions when proposed by their political parties and dismissed as members of political parties in accordance with the provisions of legislation. More clearly in Article 16 paragraph (1) of Law Number 2 Year 2008 regarding Political Parties as amended by Law Number 2 Year 2011 on Amendment to Law Number 2 Year 2008 regarding Political Party (Political Party Law) Members of Political Parties shall be dismissed from Political Parties if:

1. died;

2. to resign in writing;

3. being a member of another Political Party; or

4. violate $\mathrm{AD}$ and ART. ${ }^{6}$

Arrangements for dismissal of members of political parties that have been regulated in the law, indirectly have an influence on the existence of existing members in parliament. Article 16 paragraph (3) of the Political Party Law further explains that "In the event that a member of a dismissed Political Party is a member of a representative body of the people, the dismissal from membership of a Political Party shall be followed by the dismissal of membership in a representative body in accordance with the law."

Arrangements on the recall of political parties have actually experienced dynamics from time to time. The regulation of political party recall has existed since Soekarno's reign, but never disappeared from the legislation at the beginning of the reformation period with Law Number 2 Year 1999 (on Political Parties) and Law Number 4 Year 1999 (regarding Arrangement and Status The People's Consultative Assembly, the People's Legislative Assembly, and the Regional People's Legislative Assembly), the recall is excluded, recall except for the inevitable reasons of dying, resigning, or being sentenced with certain qualifications.

\footnotetext{
${ }^{6} \mathrm{AD}$ refer to articles of association, and ART refer to bylaws.
} 
However, subsequent to the amendment of the 1945 Constitution which contains the provisions of Article 22 $\mathrm{B}^{7}$ (Second Amendment, Year 2000), the regulation on the right of recall of political parties is stated again in Law Number 22 Year 2003 regarding the Composition and Position of the People's Consultative Assembly, The People's Legislative Assembly, the Regional Representatives Council and the Regional People's Legislative Assembly and Law Number 31 Year 2002 on Political Parties.

The existence of the regulation on the right of recall of political parties, has led to a polemic in the constitutional process. It is seen by the process of judicial review to the Constitutional Court in 2006 with the Decision of the Constitutional Court of the Republic of Indonesia no. 008 / PUU-IV / 2006 concerning the Judicial Review of Law Number 22 Year 2003 regarding the Composition and Status of MPR, DPR, DPD and DPRD and Law Number 31 Year 2002 on Political Parties Against the 1945 Constitution, and in 2010 by Court Decision Constitution of the Republic of Indonesia No.38 / PUU-VIII / 2010 concerning the Judicial Review of Law Number 27 Year 2009 concerning the People's Consultative Assembly, the People's Legislative Assembly, the Regional Representative Council and the Regional People's Legislative Assembly.

The other side, in the implementation of the use of recall rights of political parties is also causing much controversy. The latest case of the use of recall rights of political parties is in the dismissal of deputy chairman of the House of Representatives Fahri Hamzah who came from the Prosperous Justice Party (PKS). Fahri Hamzah has been sacked by his party in March 2016. This inter-time stoppage or recall of Fahri Hamzah is based on the grounds of having been in the statutes and by-laws of the party. ${ }^{8}$

Based on the above description, the authors are interested to examine the politics of political rights recall political party relevance to the sovereignty system of the people in the dynamics of state administration of Indonesia through the study of legal doctrines, principles of law and the provisions of legislation regulating the rights recall political parties.

\footnotetext{
${ }^{7}$ Article 22B of the 1945 Constitution state that Members of the People's Legislative Assembly may be dismissed from office, whose terms and ordinances are governed by law.

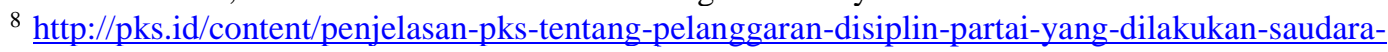
fahri-hamzah accessed on August 29, 2017 at 20:00 pm
} 


\section{METHOD}

This research is conducted by corridor of doctrinal research which only use secondary data. The legal research model is a comprehensive and analytical study of primary legal materials and secondary legal materials. The problem approach uses statute approach and conceptual approach. ${ }^{9}$ The data were analyzed qualitatively by describing the data generated from the research into the form of explanation systematically so as to obtain a clear picture of the problem under study, the results of data analysis deductive concluded.

\section{RESULTS AND DISCUSSION}

\section{Arrangement of the Recall Right of Political Parties in the Legislation}

Harun Al Rashid points out that the Inter-Time Dismissal or so-called Recall is the right of a political party to withdraw the elected parliamentarian through the list of candidates it submits. ${ }^{10}$ In line with the opinion of Harun Al Rashid, long before Indonesia entered the reform era, Muhammad Hatta stated that the recall rights of undisputed political parties were only known in the communist countries, with the view that the party is everything and as if sovereign parties. ${ }^{11}$

Denny Indrayana reveals that the recall is a mechanism to dismiss a lawmaker before his term expires. ${ }^{12}$ The same thing, J.J.A. Thamassen also stated that Recall Recht: het recht van een politieke partij om een via haar kandidaten lijst gekozen parlementslid terug te reopen. Thus, the recall is the right of a political party to withdraw the elected parliamentarian through the list of candidates it submits. ${ }^{13}$ Recall in the MD3 Law is referred to as a stop interchange of time.

Arrangement of members of the DPR in the context of history in Indonesia has experienced dynamics. During the reign of President Soekarno, recall of MPs was possible and even the implementation was very authoritarian. Because of the permissive use of

${ }^{9}$ Mahmud, Peter. (2005). Penelitian Hukum. Jakarta: Kencana Prenada, p. xx.

${ }^{10}$ Decision of the Constitutional Court of the Republic of Indonesia No. 008 / PUUIV / 2006 on Tests of Law Number 22 Year 2003 on the Composition and Position of MPR, DPR, DPD, and DPRD and Law Number 31 Year 2002 on Political Parties Against the 1945 Constitution.

${ }^{11}$ Mahendra, Yusril Ihza. (1996). Dinamika Tatanegara Indonesia: Kompilasi Aktual Masalah Konstitusi, DPR dan Sistem Kepartaian. Jakarta: Gema Insani Press, p. 171.

${ }^{12}$ Decision of the Constitutional Court of the Republic of Indonesia in Case No.008 / PUU-IV / 2006..., Op.Cit.

${ }^{13}$ J.J.A. Thamassen (red). (1981). Democratie, Theorie en Praktijk, Alphen aan den Rijn, Brussel, Samson Uitgeverij, p. 156, cited from Decision of the Constitutional Court of the Republic of Indonesia in Case No.008 / PUU-IV / 2006..., ibid. 
recall rights at that time, no less than a Muhammad Hatta criticized the recall. When the period of the recall arrangement is regulated in Article 13 of Law Number 10 Year 1966 regarding the Position of the Provisional People's Consultative Assembly and the People's Representative Council of Gotong Royong Approaching the General Election, stating that "The appointment and dismissal of members of the MPRS and DPR-GR shall be stipulated by such agency article 4 or by such party / organization / agency in article 15 for further through the leadership of MPRS / DPR-GR authorized by the President. "

The setting and practice of recall also continued during the Soeharto regime during the New Order era. The regulation of recalls in the New Order era is explicitly construed in the legislation on the basis of juridical Article 4 of Law Number 16 Year 1969 on the Composition and Position of the People's Consultative Assembly, the People's Legislative Assembly, and the Regional People's Legislative Assembly (Dewan Perwakilan Rakyat). Recall at the time was used as a weapon to silence politicians who did not follow the rhythm of the strains of the president. Bung Hatta once criticized the right of recall and requested that the House revoke it. He also deplored the jurists who were silent when the recall right was processed in the DPR. ${ }^{14}$

Conditions changed in 1998 when Suharto resigned, ${ }^{15}$ demands to remove recall agencies (stopping half way) against members of Parliament / DPRD has been raised in the New Order era. The existence of recall system caused many people's representatives to become uncritical, even afraid to voice the aspirations of the people. In the reform era, recall was successfully abandoned, recall except for the inevitable reason of death, resignation, or sentence of criminal with certain qualification. ${ }^{16}$ This can be seen in Law Number 4 Year 1999 on the Composition and Position of the People's Consultative Assembly, the People's Legislative Assembly, and the Regional People's Legislative Assembly (Dewan Perwakilan Rakyat).

In the period following the amendment of the 1945 Constitution which contains the provisions of Article 22B (Second Amendment, Year 2000), the replacement of members of Parliament is again mentioned in Article 85 of Law Number 22 Year 2003 on the

\footnotetext{
${ }^{14}$ Refer to Harian Kompas, March 1, 1973. Cited from Harun Al-Rasyid inside Decision of the Constitutional Court of the Republic of Indonesia in Case No.008 / PUU-IV / 2006.., Op.Cit.

${ }^{15}$ Yulius P. Hermawan inside Sugeng, Bob dan Schuck, Christoph. (2010). Demokrasi di Indonesia: Teori dan Praktik. Yogyakarta: Graha Ilmu, p. 99.

${ }^{16}$ Mahfud MD, Moh. (2010) Perdebatan Hukum Tata Negara (Pasca Amandemen Konstitusi). Jakarta: PT Raja Grafindo Persada, p. 165.
} 
Composition and Position of the People's Consultative Assembly, the House of Representatives, and the Regional People's Legislative Assembly, as well as in Law Number 31 Year 2002 on Political Parties. According to Mahfud MD, the reason for the return of recall arrangements because the leadership of political parties is expected to supervise and hinder members of Parliament / DPRD who commit disgraceful acts such as selling votes against the head of the region. ${ }^{17}$ However, once the recall setting is revived, the party's management can threaten (and already proven to be) recalling its members for reasons that are still controversial. ${ }^{18}$ Re-enactment of recall rights by granting the authority of political parties to dismiss their members in the DPR shows that the existence of political parties is retreating back to authoritarian times. ${ }^{19}$ In the history of Indonesia the right of recall was revived in the regime of President Soeharto, and therefore on the spirit of recall rights reform was eliminated for the 1999 elections.

The next arrangement as regulated in Law Number 27 Year 2009 is still the same that impose the right of recall of political parties. The arrangement of the recall of members of the People's Legislative Assembly provided in the law provides that the recall of members of Parliament conducted by political parties is not required to investigate and verify by the Honor Board and the absence of any legal remedy that can be done by the members of the Council if they object. This gives an enormous amount of authority to political parties to dismiss members who are members of the DPR who can only be based on their likes or dislikes or against party policies.

Further development, the existence of a change of law that is with Law No. 17 of 2014. In this arrangement is basically the same that is the right of recall given to political parties. However, the difference in this latest arrangement, there is room in providing opportunities for board members to take legal action if they object. The clause is stated in Article 241 paragraph (1) stating that "In the event that a member of a political party is dismissed by its political party as referred to in Article 239 paragraph (2) letter $\mathrm{d}$ and concerned appeals by court, its dismissal is valid after a court decision has been obtaining a permanent legal force. "

\footnotetext{
${ }^{17}$ The existence of the rule that the regional head is elected by the DPRD in Law Number 22 of 1999 on Regional Government.

${ }^{18}$ Mahfud MD, Perdebatan Hukum Tata Negara ... Op.Cit.

${ }^{19}$ Arbi Sanit, inside Decision of the Constitutional Court of the Republic of Indonesia in Case No.008 / PUU-IV / 2006..., Op.Cit.
} 
Based on the analysis of the dynamics of the regulation of recall rights of political parties above, the authors

\section{The Relationship Between a Political Party, a Representative Body of People, and an Electoral System}

Political parties are a necessity in democratic modern political life. As an organization, political parties are ideally meant to activate and mobilize the people, to represent a particular interest, to provide a compromise way for competing opinions, and to maximize legitimate and peaceful political leadership. ${ }^{20}$ It can be argued that the political party in essence has a status (position) and a role (role) is central and important in every democratic system. Political parties are commonly referred to as pillars of democracy, because they play an important role as a link between the state government and its citizen. ${ }^{21}$

Political Parties as stipulated in Article 11 of the Political Party Law, have the function of one of them is as a means of political recruitment in the process of filling political office through democratic mechanisms by taking into account gender equality and justice. The function of political recruitment inherent in the political party is one of them as the process of filling members of the House.

Parliament as part of the representative body of the people who are present in the Indonesian state administration system is a manifestation of the implementation of the mandate of the 1945 Constitution. To be eligible for membership of the People's Legislative Assembly, a person shall be elected through a general election held once every five years as provided in Article 19 paragraph 1) juncto Article 22E Paragraph (1) and (2) of the 1945 Constitution. $^{22}$

Political parties are placed as participants in an election to elect members of Parliament. This proposition is expressly stated in Article 22E Paragraph (3) of the 1945 Constitution states that "election participants to elect members of the People's Legislative

\footnotetext{
${ }^{20}$ Fadjar, Abdul Mukthie. (2012). Partai Politik dalam Perkembangan Ketatanegaraan Indonesia, Malang: Setara Press, p. 13.

${ }^{21}$ Asshiddiqie, Jimly. (2008). Pokok-Pokok Hukum Tata Negara Indonesia Pasca Reformasi. Jakarta: PT Bhuana Ilmu Populer, p. 710. Sigmund Neumann argues that political parties are: "An articulate organization composed of active political actors in society, those who focus on the control of governmental power and those competing for popular support, with some other groups having different views - different." Abdul Mukthie Fadjar, Ibid.,p. 14

${ }^{22}$ Article 19 Paragraph (1) of the 1945 Constitution reads "Members of the Council of Representatives of Rayat are elected by general election." Article 22E Paragraph (1) reads "Elections shall be conducted in a direct, public, free, secret, honest and fair manner every five years." Furthermore, paragraph (2) reads, "General Elections shall be held to elect members of the People's Legislative Assembly, Regional Representatives Council, President and Vice President and Regional People's Representative Council".
} 
Assembly and members of the Regional People's Legislative Assembly shall be political parties."

The election to elect members of DPR, Provincial DPRD, and Regency / Municipal DPRD shall be implemented with an open proportional system. ${ }^{23}$ It is stipulated in Article 168 paragraph (2) of Law Number 7 Year 2017 on General Election. Through an open proportional system the people no longer only choose the party's signals but are directly drawn against the candidates to be elected to sit in parliament. In an open proportional system, who gets the most votes he chooses without questioning the serial number.

The electoral system in Indonesia has in fact changed over time. The 1999 elections adopted a proportional representation system with a closed list. ${ }^{24}$ So that the closed list system of proportional representation gives the party authority to determine the elected MPs and councils. The consequence of this system is that the people's representatives must first represent the party rather than their constituents. This is based on the fact that the people (voters) give their votes to the Party, not directly to the people's representatives. ${ }^{25}$

The 2004 elections adopted an open list system to select members of the DPR, Provincial and Regency / Municipal DPRDs. ${ }^{26}$ Through this system, voters choose both parties and candidates. However only the candidate who gets the vote reaches the "Voter Sharing Voters" which can be declared elected. If the election participants do not reach the "Voter Shares", then the subsequent determination is based on the serial number.

In its development, initially the electoral system in 2009 also used a proportional system with open lists. ${ }^{27}$ However, through the Constitutional Court Decision Number 2224 / PUU-VI / 2008, has changed the electoral system into an open proportional system

${ }_{23}$ The Electoral System is a method or method for transferring electoral votes to a representative body. Through a particular electoral system, the transformation of the people's sovereignty is manifested in the voting process to achieve certain political positions. se

${ }^{24}$ Pasal 1 ayat (7) Undang-Undang Nomor 3 Tahun 1999 tentang Pemilihan Umum, bahwa "Pemilihan Umum dilaksanakan dengan menggunakan sistem proporsional berdasarkan stelsel daftar." Article 1 paragraph (7) of Law Number 3 Year 1999 regarding General Election, that "General Election is conducted by using proportional system based on list stelsel."

${ }^{25}$ Yulius P. Hermawan, Op.Cit., p. 135.

26 This is stipulated in Article 6 paragraph (1) of Law Number 12 Year 2003 regarding General Election of members of the People's Legislative Assembly, Regional Representatives Council, and Regional House of Representatives, stating that "General Election to elect members of DPR, Provincial DPRD and Regency DPRD / The city is implemented by a proportional system with an open list of candidates. "

${ }^{27}$ Article 5 Paragraph (1) of Law Number 10 Year 2008 regarding General Election of Members of the People's Legislative Assembly, Regional Representative Council, and Regional House of Representatives, which states that "Elections to elect members of DPR, Provincial DPRD and Regency / Municipal DPRD shall be implemented with an open proportional system. " 
with the application of the most votes. Based on the Constitutional Court's decision, the placement of sequential numbers is considered as a form of political party oligarchy that negates the will of the people in determining their representatives.

Regarding the electoral system, it can be observed that the more the electoral system provides more and more space for the people to decide for themselves, the system will be closer to the nature of popular sovereignty. The more the system narrows the space for the people to make their choice, the system will further away from the sovereignty of the 1945 Constitution. ${ }^{28}$ This is in accordance with the opinion of Valina Singka Subekti, that the electoral system is political engineering, political engineering tool, so the choice of one system the election is related to the ultimate goal to be achieved. ${ }^{29}$

According to Miriam Budiardjo, members of political parties elected based on a proportional system with an open list of candidates constitutionally can not be recalled by his party. ${ }^{30}$ Recalling the concerned member of the council means denying or negating the results of popular elections as the holder of sovereignty. Elections with the highest number of votes indicate that the choice depends on the people, no longer based on the authority of the political party by placing the serial number. Members of the People's Legislative Assembly representing the people, in the name of the Members of the People's Legislative Assembly, are essentially statesmen. He can not simply extend his party's hand.

Thus, the function of political parties as a means of political recruitment should be completed with the election of legislative candidates which are the result of the people's choice. Therefore, political parties should not be eligible to replace elected candidates unless they have the consent of the people who have elected them.

\section{The Legal Politics of the Recall Rights of Political Parties as Instruments of Leadership of Political Parties in Controlling Their Existing Members in Parliament}

Experts differ on the legal definition of law; Padmo Wahjono said that legal politics is the basic policy that determines the direction, shape, and content of the law to be 6.

${ }^{28}$ Fahmi, Khairul. (2011). Pemilihan Umum dan Kedaulatan Rakyat. Jakarta: PT RajaGrafindo, p.

${ }^{29}$ Ibid., p. 215

${ }^{30}$ Decision of the Constitutional Court of the Republic of Indonesia in Case No.008 / PUU-IV / 2006..., Op.Cit. 
formed. ${ }^{31}$ Satjipto Rahardjo defines the politics of law as the activity of choosing and the means to be used to achieve a social goal with certain laws in society. ${ }^{32}$ As for Mahfud MD argues that legal politics is a legal policy or an official (policy) line of law that will be enforced either by the creation of a new law or with the replacement of the old law, in order to achieve the objectives of the State. ${ }^{33}$

The concept of legal politics to be used is the concept of Mahfud MD which gives the following proposition: in the context of law as a political product, democratic political configuration will produce responsive law, whereas authoritarian political configuration will lead to orthodox or conservative law. ${ }^{34}$

Responsive or populistic legal products are legal products that reflect a sense of justice and meet community expectations. In the process of making it gives a big role and full participation of social groups or individuals in society. While conservative or orthodox legal products are legal products whose content more reflects the social vision of the political elite, more reflective of the wishes of the government, is positivist-instrumentalist, namely being a tool of state ideology and program implementation. ${ }^{35}$ Using this concept will be seen the political law of recall rights arrangements in the Indonesian state administration system.

The regulation of recall of political parties as stipulated in the Law on MD3 provides no clear restriction on the reasons for the dismissal between members of the legislature when proposed by their political parties. In contrast, in the provisions of Article 240 , it contains only administrative rules in the dismissal of such legislative members. Article 240:

(1) Dismissal of members of the People's Legislative Assembly as referred to in Article 239 paragraph (1) a and b as well as in paragraph (2) letter c, letter d, letter g, and letter $h$ is proposed by the leadership of a political party to the leadership of the DPR with copies to the President .

(2) The maximum of 7 (seven) Days from the receipt of the proposed dismissal as referred to in paragraph (1), the leadership of the People's Legislative Assembly shall submit a proposal for dismissal of members of the People's Legislative Assembly to the President to obtain the inauguration of the dismissal.

\footnotetext{
${ }^{31}$ Wahjono, Padmo. (1986). Indonesia Negara Berdasarkan Atas Hukum. Jakarta: Ghalia Indonesia, p. 160. inside Mahfud MD, Moh. (2012). Politik Hukum di Indonesia. Jakarta: RajaGrafindo Persada, p.1.

${ }^{32}$ Rahardjo, Satjipto. (1991). Ilmu Hukum. Bandung: Citra Aditya Bakti, p. 352-353.

${ }^{33}$ Mahfud MD, Moh., Politik Hukum di Indonesia, ... Op.Cit., p. 2.

${ }^{34}$ Ibid., p. 7.

${ }^{35}$ Ibid., p. 31-32
} 
(3) The President shall inaugurate the dismissal as referred to in paragraph (2) no later than 14 (fourteen) days after the receipt of the proposed dismissal of DPR members from the DPR leadership.

Based on these provisions, according to the authors in this case the role of leaders of the House and the President is limited to only authorization, the authority remains in the leadership of political parties. In addition, in the Political Party Law also does not regulate in detail the dismissal of membership of political parties, in Article 16 paragraph (1) only provides that Members of Political Parties are dismissed from Political Party if:

1. died;

2. to resign in writing;

3. being a member of another Political Party; or

4. violate $\mathrm{AD}$ and $\mathrm{ART}$.

The political party's domination of its members sitting in representative institutions is very big. Political parties may use the instrument of recall of political parties constitutionally to enforce its members in parliament to follow what the party instructs.

Legal policy on recall rights is strongly influenced by the political will (political will) supra political structure (government and parliament) and political infrastructure (political party) itself which is not always in accordance with the nature of people's sovereignty and the fact that members of the People's Legislative Assembly as representative of the people, party. Recalling by a political party of its members sitting in a representative institution for the reason of violation of the ART does not guarantee the due process of law which is one of the principles of the rule of law, as it may be a subjective leader of a political party that is difficult to control by the public. ${ }^{36}$ Harun Al Rashid quoted Manual Luis Quezon, a former Philippine President who said, when a person is elected to parliament, he says "my loyalty to my party ends when my loyalty to my country begins" which means my loyalty to the party ends when my loyalty to the homeland and the nation began. ${ }^{37}$

The provision of this recall is a redundant provision and is excluded from the domain of the Political Party's power, since the terms of the criteria for the reasons for dismissal of a member of a political party that is a member of the People's Legislative Assembly have been accommodated and become the authority of the Council of Honor Board. The

\footnotetext{
${ }^{36}$ Dissenting Opinion inside Decision of the Constitutional Court of the Republic of Indonesia in Case No.008 / PUU-IV / 2006 Putusan Mahkamah Konstitusi Republik Indonesia dalam Perkara No.008/PUU-IV/2006..., Op.Cit.

${ }^{37}$ Putusan Mahkamah Konstitusi Republik Indonesia dalam Perkara No.008/PUU-IV/2006 Decision of the Constitutional Court of the Republic of Indonesia in Case No.008 / PUU-IV / 2006..., Op. Cit.
} 
mechanism of recall should be avoided by the people should be avoided because it will lead to party oligarchy. ${ }^{38}$

Muhammad Hatta stated that the recall rights of an inviolable political party are known only in the communist countries with the view that the party is everything and as if it is a sovereign party. ${ }^{39}$ Robert Michels also specifically rejects the presumption of representation leadhership, since most of the policies of mass organizations do not reflect the will and interests of the masses, but reflect the will and interests of the leader. ${ }^{40}$ Organizations and also political party organizations sometimes act out loud for and on behalf of the interests of the people, but in reality on the ground it is fighting for the benefit of its own board. ${ }^{41}$

This is illustrated by the fact that the political parties make the recall as a tool to control the members of the council so that the members of the council are subject to the policies made by political parties. So indirectly, the parliamentarians in the parliament are fighting for the interests of the political parties that overshadowed him and this has led to the fact that members of the DPR are no longer representative of the people, but are representative of a group of people within the Political Party. Therefore, according to the authors of the right of recall owned by political parties to their members in parliament does not reflect the principle of people's sovereignty, the recall will only serve as a pre-requisite for political parties to channel the interests of political parties. Arbi sanit also revealed that viewed from the perspective of political science and government shows irrelevansi rights recall with the process of democracy is carried out reformatively. ${ }^{42}$

Meanwhile, the 1945 Constitution also does not expressly give recall rights to political parties in order to recall members of their elected party as members of DPR. The right of recall is not initiated by the founding fathers in BPUPKI / PPKI meetings during the constitutional review. It is also not proposed in the sessions of the MPR at the time of

\footnotetext{
${ }^{38}$ Denny Indrayana, Ibid.

${ }^{39}$ Muhammad Hatta, inside Yusril Ihza Mahendra,...Op.Cit.,p. 171.

${ }^{40}$ Seymour Martin Lipset, Pengantar untuk edisi bahasa Inggris, inside Michels, Robert. (1984). Partai Politik Kecenderungan Oligharki dalam Birokrasi. Jakarata: Rajawali, p. Xxvii.

${ }^{41}$ Assiddiqie, Jimly. (2006). Kemerdekaan Berserikat Pembubaran Partai Politik dan Mahkamah Konstitusi. Jakarta: Konstitusi Press, p. 68.

${ }^{42}$ Putusan Mahkamah Konstitusi Republik Indonesia dalam Perkara No.008/PUU-IV/2006 Decision of the Constitutional Court of the Republic of Indonesia in Case No.008 / PUU-IV / 2006..., Op. Cit.
} 
the amendments of the 1945 Constitution. The right of recall does not include constitutional given for political parties. ${ }^{43}$

When listening to the history of the Indonesian constitution, the framers of the constitution, embracing the theory of the representative as a trustee means that the people's representatives have the freedom to act and be given full trust. ${ }^{44}$ This is reflected in Article 90 of the 1949 Constitution of the Republic of Indonesia which states that, "Members of the People's Legislative Assembly shall issue their votes as free men, in their feelings and inner honor, not on the orders and obligations of consultation with the person appointing them as members."

Thus, according to the authors, the rule of law on recall rights of political parties today has a more conservative or orthodox character.

\section{CONCLUSION}

Based on the previous section, it can be concluded that Political law of recall rights of political parties is basically an instrument of leadership of political parties in controlling its members in parliament. The existence of the party's recall rights order becomes a legitimacy for the party leadership to control its members to always follow the direction of party policy. The consequences that arise, the dismissal of legislative members by political parties has caused much controversy because the reasons for dismissal are often based on subjective reasons. This makes board members more loyal to political parties than the people they are supposed to represent.

\section{BIBLIOGRAPHY}

[1] Asshiddiqie, Jimly. (1994). Gagasan Kedaulatan Rakyat Dalam Konstitusi dan Pelaksanaannya Di Indonesia. Jakarta: PT Ichtiar Baru Van Hoeve. (2008). Pokok-Pokok Hukum Tata Negara Indonesia Pasca

Reformasi. Jakarta: PT Bhuana Ilmu Populer. . (2006). Pengantar Ilmu Hukum Tata Negara Indonesia. Jakarta: Sekretariat Jenderal dan Kepaniteraan Mahkamah konstitusi.

[4] __ (2006). Kemerdekaan Berserikat Pembubaran Partai Politik dan Mahkamah Konstitusi. Jakarta: Konstitusi Press.

\footnotetext{
${ }^{43}$ HM.Laica Marzuki, ibid.

${ }^{44}$ Surbakti, Ramlan. (1992). Memahami Ilmu Politik. Jakarta: Gramedia Widyasarana, p.174.
} 
[5] Fadjar, Abdul Mukthie. (2012). Partai Politik dalam Perkembangan Ketatanegaraan Indonesia, Malang: Setara Press.

[6] Fahmi, Khairul. (2011). Pemilihan Umum dan Kedaulatan Rakyat. Jakarta: PT RajaGrafindo.

[7] Kusnardi, Moh. dan Ibrahim, Harmaily. (1983). Pengantar Hukum Tata Negara Indonesia. Jakarta: PSHTN FHUI.

[8] Mahendra, Yusril Ihza. (1996). Dinamika Tatanegara Indonesia: Kompilasi Aktual Masalah Konstitusi, DPR dan Sistem Kepartaian. Jakarta: Gema Insani Press.

[9] Mahfud MD, Moh. (2010) Perdebatan Hukum Tata Negara (Pasca Amandemen Konstitusi). Jakarta: PT Raja Grafindo Persada.

[10] . (2012). Politik Hukum di Indonesia. Jakarta: RajaGrafindo Persada.

[11] Mahmud, Peter. (2005). Penelitian Hukum. Jakarta: Kencana Prenada.

[12] Michels, Robert. (1984). Partai Politik Kecenderungan Oligharki dalam Birokrasi. Jakarata: Rajawali.

[13] Rahardjo, Satjipto. (1991). Ilmu Hukum. Bandung: Citra Aditya Bakti.

[14] Sugeng, Bob dan Schuck, Christoph. (2010). Demokrasi di Indonesia: Teori dan Praktik. Yogyakarta: Graha Ilmu.

[15] Surbakti, Ramlan. (1992). Memahami Ilmu Politik. Jakarta: Gramedia Widyasarana.

[16] Tricahyo, Ibnu. (2009). Reformasi Pemilu Menuju Pemisahan Pemilu Nasional dan Lokal. Malang: In-Trans Publishing.

[17] Wahjono, Padmo. (1986). Indonesia Negara Berdasarkan Atas Hukum. Jakarta: Ghalia Indonesia.

[18] Yasir, Armen. (2010). Makalah Bahan Kuliah Politik Hukum. Lampung: Universitas Lampung. 